\title{
Pumpkin Seed Oil
}

National Cancer Institute

\section{Source}

National Cancer Institute. Pumpkin Seed Oil. NCI Thesaurus. Code C107351.

The oil extracted from the seeds of Cucurbita pepo var. styriaca. Pumpkin seed oil is used primarily as a food flavoring. 